\title{
SANITATION OF CHICKEN SLAUGHTERING BUSSINESS WITH CRITICAL DISORDERS
}

\author{
${ }^{1}$ Radillah, ${ }^{2}$ Andi Alim, ${ }^{3}$ Hidayat \\ ${ }^{12}$ Fakultas Kesehatan Masyarakat UPRI Makassar \\ ${ }^{3}$ Poltekkes Makassar
}

\begin{abstract}
The existence of Chicken Slaughtering Bussiness (CSB) being located in the middle of the settlement makes people disturbed the comfort of waste generated such as smell, sewage, vector to the people who live around the CSB in Urban Village East Bara-Baraya. The purpose of this research is to know the description of environmental sanitation of Chicken Slaughtering Bussiness with disturbance of comfort, in Urban Village East Bara-Baraya District of Makassar city. The method of this research is descriptive with observation approach to see description between disturbance of comfort, smell, liquid waste, and vector. The number of samples in this study was 42 samples. The results showed that most of the CSB in Urban Village East Bara-Baraya caused an unpleasant smell that made the community around the slaughterhouse feel uncomfortable. Waste disposal from cutting process is thrown away to drainage channel causing unpleasant odour which makes the society of Urban Village East Bara-Baraya disturbed comfort. There is a vector around the dumpster and sewerage channel of Chicken Slaughtering Bussiness that makes the transmission of seeds of disease to the community around CSB so that often family members affected by diseases such as diarrhoea, fever and wormy in children. Suggestions for the research are suggested to CSB owners to maintain the cleanliness of chicken coop and throw away the remaining processed chicken away from community settlements in order not to cause odour. The need for the government to issue a policy on the prohibition of disposing waste chicken processed waste into sewerage channels around the community environment of Urban Village East Bara-Baraya. It is expected that health workers to provide counselling on how to prevent the occurrence of infectious diseases caused by existing vectors in the community of Urban Village East Bara-Baraya.
\end{abstract}

Keywords: Chicken Slaughtering Bussiness, Sanitation and Vektor 
PENDAHULUAN

Derajat kesehatan masyarakat merupakan salah satu indikator harapan hidup manusia yang harus dicapai, untuk itu diperlukan upayaupaya dalam mengatasi masalah kesehatan masyarakat. Salah satu upaya yang dilakukan adalah mengatasi masalah-masalah sanitasi yang dapat mengganggu kesehatan. Sanitasi lingkungan merupakan satu dari masalah-masalah sanitasi tersebut (Mulia, 2005).

Sanitasi adalah upaya kesehatan dengan cara memelihara dan melindungi kebersihan lingkungan dari subjeknya, misalnya menyediakan air bersih untuk keperluan mencuci tangan, menyediakan tempat sampah agar tidak dibuang sembarangan (Depkes RI, 2004). Batasan pengertian sanitasi menurut WHO adalah pengawasan Rumah Potong Ayam pembuangan tinja, limbah cair, padat, vektor penyakit, kondisi perumahan, penyediaan dan penanganan makanan, kondisi atmosfer dan keselamatan lingkungan kerja. Kondisi peredaran ayam telah menimbulkan permasalahan kesehatan lingkungan. Proses pengangkutan dalam truk terbuka dapat menebarkan bakteri dan virus penyebab berbagai penyakit di sepanjang jalan yang dilaluioleh unggas tersebut hingga ke tempat penampungan. Selain itu, kondisi tempat pemotongan ayam yang berada di rumahrumah penduduk serta dekat dengan pemukiman penduduk menimbulkan berbagai permasalahan pencemaran lingkungan dan memperburuk masalah sanitasi di pemukiman. Kondisi tersebut juga tidak baik untuk ayam potong yang dihasilkan karena selama proses pemotongan, pembersihan dan pengepakan ayam dilakukan dalam satu tempat, sehingga rawan terjadi kontaminasi dari berbagai sumber penyakit (Tjiptadi, 1990).

Pengolahan limbah yang belum dikelola dengan baik oleh rumah pemotongan ayam yang berada dekat dengan lingkungan masyarakat tentu saja berdampak pada masyarakat sekitar baik secara langsung maupun tidak. Untuk itu, pemotong unggas diarahkan menampung, mengolah limbahnya dan tidak membuangnya ke saluran umum.

Umumnya para oknum Tempat Pemotongan Ayam (TPA) yang kurang baik melakukan tidakan tersebut dikarenakan kurangnya 
pengetahuan, kurangnya pembinaan dari instansi terkait serta kurangnya pengawasan dari instansi terkait tempat pemotongan ayam yang berada di rumah-rumah penduduk serta dekat dengan pemukiman penduduk menimbulkan berbagai permasalahan pencemaran lingkungan dan memperburuk masalah sanitasi di pemukiman.

Kondisi tersebut juga tidak baik untuk ayam potong yang dihasilkan karena selama proses pemotongan, pembersihan dan pengepakan ayam dilakukan dalam satu tempat, sehingga rawan terjadi kontaminasi dari berbagai sumber penyakit (Tjiptadi, 1990).

Kebutuhan masyarakat Kelurahan Bara-Baraya Timur akan daging ayam semakin meningkat. Daging yang berkualitas dipengaruhi oleh beberapa faktor, meliputi higiene dan sanitasi Tempat Pemotongan Ayam (TPA), distribusi daging ayam ke penjual, dan cara penjualannya. Penanganan yang dilakukan di TPA yaitu mulai dari cara pemotongan sampai dengan cara penanganan karkas ayam. Daging ayam sebelum dijual harus melalui proses pendistribusian yaitu dengan dimasukan ke kotak pendingin, ini dimaksudkan untuk menjaga kesegaran daging. Penanganandistribusi daging yang salah dapat menyebabkan pembusukan yang cepat. Selain Penanganan daging ayam di TPA dan cara pendistribusian daging ayam yang baik juga diperlukan penanganan daging pada saat penjualan agar daging tetap segar dan tidak cepat busuk.

Keberadaan

rumah

pemotongan ayam yang terdapat ditengah-tengah pemukiman penduduk tersebut membuat masyarakat terganggu kenyamanan dengan limbah yang ditimbulkan seperti bau, limbah, vektor terhadap masyarakat yang bermukim disekitar RPA berada di Kelurahan Bara- Baraya Timur.

Kondisi peredaran ayam telah menimbulkan permasalahan kesehatan lingkungan. Proses pengangkutan dalam truk terbuka dapat menebarkan bakteri dan virus penyebab berbagai penyakit di sepanjang jalan yang dilaluioleh mobil yang membawa unggas tersebut hingga ke tempat penampungan ini menyebabkan gangguan kenyamanan. RPA berfungsi sebagai pasar unggas hidup dan jasa pemotongan unggas yang dalam kegiatannya seharusnya memperhatikan faktor-faktor berkaitan dengan sanitasi 
lingkungan. Sanitasi lingkungan mencakup penanganan limbah dan bau. Penelitian ini bertujuan menggambarkan kondisi sanitasi di rumah potong ayam yang berada di Kecamatan Bara-Baraya Timur.

\section{BAHAN DAN METODE}

Desain penelitian ini adalah (Deskriptif) dengan pendekatan observasi. Penelitian ini telah dilaksanakan di Kelurahan Bara-Baraya Timur Kecemtan Makaassar Kota
Makassar. Dilaksanakan dari bulan Juni - Juli 2016. Populasi dalam penelitian ini adalah keseluruhan masyarakat yang berada di Kelurahan BaraBaraya Timur.Adapun jumlah masyarakat yang berada di daerah tersebut sebanyak 912 jiwa.

Sampel adalah 42 responden. Dengan cara pengambilan sampel yaitu dengan menggunakan teknik simpel random sampling.

\section{HASIL}

\section{Umur}

Tabel.1

Klasifikasi responden berdasarkan umur

\begin{tabular}{ccc}
\hline $\begin{array}{c}\text { Umur } \\
\text { (tahun) }\end{array}$ & n (orang) & Persentase (\%) \\
\hline $17-27$ & 9 & 21,42 \\
$28-38$ & 8 & 19,04 \\
$39-49$ & 13 & 30,95 \\
$50-60$ & 11 & 26,19 \\
$61-75$ & 1 & 2,38 \\
Jumlah & $\mathbf{4 2}$ & $\mathbf{1 0 0}$ \\
\hline
\end{tabular}

Sumber: Data Primer 2016

Pada Tabel 1 menunjukkan bahwa persentase tingkat umur yang tertinggi dari responden yang tinggal di Kelurahan BaraBaraya timur Kecamatan Makassar Kota Makassar adalah klasifikasi responden yang berumur 39-49 tahun dengan jumlah 13 orang dan klasifikasi yang terendah adalah responden yang berumur 61 - 75 tahun dengan jumlah 1 orang. Kondisi ini menunjukkan

bahwa responden lebih banyak dalam kategori umur produktif yang dijumpai pada waktu wawancara. 
Jenis kelamin

\section{Tabel 2.}

Klasifikasi Responden Berdasarkan Jenis Kelamin

\begin{tabular}{lcc}
\hline \multicolumn{1}{c}{ Jenis kelamin } & n (orang) & Persentase (\%) \\
\hline Laki - laki & 24 & 57,14 \\
Perempuan & 18 & 42,86 \\
Jumlah & $\mathbf{4 2}$ & $\mathbf{1 0 0}$ \\
\hline
\end{tabular}

Sumber: Data Primer 2016

Pada Tabel 2 terlihat bahwa jumlah responden berdasarkan jenis kelamin sebagian besar adalah laki-laki yaitu sebanyak 24 orang dengan persentase $57,14 \%$ sedangkan perempuan berjumlah 18 orang dengan persentase $42,86 \%$.

\section{Pendidikan}

\section{Tabel 3.}

Klasifikasi Responden Berdasarkan Tingkat Pendidikan

\begin{tabular}{ccc}
\hline Pendidikan & n (orang) & Persentase (\%) \\
\hline SD & 3 & 7,14 \\
SMP & 6 & 14,28 \\
SMA & 25 & 59,52 \\
S1 & 5 & 11,90 \\
S2 & 2 & 4,76 \\
S3 & 1 & 2,39 \\
Jumlah & $\mathbf{4 2}$ & $\mathbf{1 0 0}$
\end{tabular}

Sumber: Data Primer 2016

Pada tabel tersebut menunjukkan bahwa sebagianbesar responden memiliki tingkat pendidikan SMA/sederajat dengan jumlah 25orang dengan persentase
$59,52 \%$ dan yang terendah responden yang memilikitingkat pendidikan S3 dengan jumlah 1 orang dengan persentase $2,39 \%$. 
Pekerjaan

Tabel 4.

Klasifikasi Responden Berdasarkan Pekerjaan

\begin{tabular}{lcc}
\hline \multicolumn{1}{c}{ Pekerjaan } & n (orang) & Persentase (\%) \\
\hline Buruh & 9 & 21,42 \\
Wiraswasta & 7 & 16,66 \\
PNS & 1 & 2,38 \\
Pedagang & 4 & 9,52 \\
Mahasiswa/pela & 5 & 11,90 \\
jar & & \\
Dosen & 2 & 4,76 \\
Dokter & 1 & 2,38 \\
Pensiunan & 4 & 9,53 \\
IRT & 9 & 21,42 \\
Jumlah & $\mathbf{4 2}$ & $\mathbf{1 0 0}$ \\
\hline
\end{tabular}

Sumber: Data Primer 2016

Dari Tabel 4 dapat dilihat

mencapai $21,42 \%$ sedangkan sebagai Dokter dan PNS hanya bahwa IRT dan Buruh yang mendominasi yaitu sebanyak 1 orang saja dengan persentase $2,38 \%$. masing-masing 9 orang dengan persentase terbesar yaitu

\section{Lama Bermukim}

Tabel 5 .

Klasifikasi Responden Berdasarkan Lama Bermukim

\begin{tabular}{ccc}
\hline $\begin{array}{c}\text { Lama } \\
\text { bermukim } \\
\text { (tahun) }\end{array}$ & n (orang) & Persentase (\%) \\
\hline $0-20$ & 13 & 30,95 \\
$21-40$ & 26 & 54,76 \\
$41-60$ & 6 & 14,29 \\
Jumlah & $\mathbf{4 2}$ & $\mathbf{1 0 0}$ \\
\hline
\end{tabular}

Sumber: Data Primer 2016

Dari Tabel dapat dilihat bahwa mayoritas responden berjarak sangat dekat dengan lokasi RPA. Pemukiman

penduduk yang berada pada jarak antara 0- 50 meter dari lokasi RPA terdapat 35 responden atau $83,33 \%$ sedangkan pada jarak 51-100 
meter terdapat 7 responden kepada masyarakat, baik itu atau $16,67 \%$. Keberadaan RPA dampak negatif maupun yang dekat dengan pemukiman dampak positif. penduduk memberikan dampak

\section{Distribusi Bau}

Tabel 6

Distribusi Frekuensi Bau Akibat Kandang Ayam Yang Kurang Bersih

\begin{tabular}{ccc}
\hline Bau akibat kandang ayam & $\mathbf{n}$ & $\begin{array}{c}\text { Persentase } \\
(\%)\end{array}$ \\
\hline Tidak bau & 5 & 11,90 \\
Bau & 37 & 88,09 \\
Jumlah & $\mathbf{4 2}$ & $\mathbf{1 0 0}$ \\
\hline
\end{tabular}

Sumber: Data Primer 2016

Pada tabel distribusi di atas menunjukan kategori perilaku dalam menyikapi bau kotoran ayam yang menganggu pernapasan dan menyebabkan polusi udara di sekitar pemukiman sehinggah

penduduk masayarakat menjadi tidak nyaman sebanyak 5 orang $(11,90)$ tidak bau, dan 37 orang $(88,09)$ bau.

\section{Distribusi Limbah Cair}

Tabel 7

Distribusi Frekuensi Limbah Cair Penyebab Pencemaran Lingkungan

\begin{tabular}{|l|c|c|}
\hline Penanganan limbah cair & n (orang) & $\begin{array}{c}\text { Persentase } \\
(\%)\end{array}$ \\
\hline Tidak bau & 5 & 11,91 \\
\hline Bau & 36 & 85,71 \\
\hline Jumlah & $\mathbf{4 2}$ & $\mathbf{1 0 0}$ \\
\hline
\end{tabular}

Sumber: Data Primer 2016

Tabel 7 Limbah cair penyebab pencemaran lingkunganini dihasilkan oleh air bersih yang telah digunakan untuk berbagai kegiatan menghasilkan limbah cair karena tidak semua air yang digunakan terikut sebagianya terbuang secara langsung ke sungai hal ini menyebabkan pencemaran air sungai dan menghasilkan 
kehidupan bagi kuman-kuman penyebab penyakit. 5 orang $(11,91 \%)$ tidak bau, dan 36 orang $(85,71 \%)$ bau.

\section{Distribusi Vektor}

\section{Tabel 8}

Distribusi Frekuensi Vektor yang ditimbulkan seperti Lalat, Nyamuk dan Bakteri

\begin{tabular}{lcc}
\hline Vektor yang ditimbulkan & $\begin{array}{c}\mathbf{n} \\
\text { (orang) }\end{array}$ & Persentase (\%) \\
\hline Tidak ada vector & 4 & 9,51 \\
Ada vector & 38 & 90,47 \\
Jumlah & $\mathbf{4 2}$ & $\mathbf{1 0 0}$ \\
\hline
\end{tabular}

Sumber: Data Primer 2016

Tabel 8 adanya vektor di RPA tersebut akibat pemilik rumah potong ayam kurang menjaga kebersihannya sehingga lalat, nyamuk, virus, dan bakteri tersebut berkembang biak 38 orang merasa gangguan kenyamanannya sebanyak 38 orang $(90,47 \%)$ dan 4 orang responden tidak merasa gangguan kenyamanannya sebanyak 4 orang $(90,47 \%)$

Tabel 9

Distribusi Frekuensi Limbah Cair Di Rumah Potong Ayam

\begin{tabular}{ccc}
\hline Limbah cair & $\mathbf{n}$ & $\%$ \\
\hline Memenuhi syarat & 2 & 20 \\
Tidak memenuhi & 8 & 80 \\
syarat & 10 & 100 \\
\hline
\end{tabular}

Sumber: Data Primer 2016

$$
\text { Pada Tabe 10. } 2 \text { RPA (20\%). }
$$

Memenuhi syarat jika limbah cair diolah dengan baik lalu dibuang kelingkungan, jumlah RPA yang tidak memenuhi syarat sebanyak 8 (80\%) RPA 
Tabel 10 Distribusi Frekuensi Vektor

\begin{tabular}{lcc}
\hline \multicolumn{1}{c}{ Vektor } & $\mathbf{n}$ & $\%$ \\
\hline Tidak ada & 2 & 20 \\
vector & & \\
$\begin{array}{l}\text { Ada vector } \\
\text { Jumlah }\end{array}$ & 8 & 80 \\
Sumber: Data Primer & $\mathbf{1 0}$ & $\mathbf{1 0 0}$ \\
\hline
\end{tabular}

Tabel 11 Ada terdapat kotoran hewan sebagai sarang vektor seperti lalat, limbah cair, yang tidak di olah sehingga berpotensi berkembang biaknya nyamuk, bakteri dan virus. sebanyak $8(80 \%)$ dan rumah potong ayam ini menjaga kebersihan sanitasi lingkungan sehingga vektor tidak ada di sekitar rumah potong ayam sebanyak $2(20 \%)$.

\section{PEMBAHASAN}

Penelitian ini dilaksanakan pada tanggal 20 Juni sampai dengan 20 Juli 2016 di Kelurahan Bara-Baraya Timur dengan metode penelitian total sampling pengumpulan data dengan menggunakan lembar kuisioner dan mengambil data dari instansi Kelurahan Bara - Baraya timur. Penelitian ini mengkaji tentang sanitasi lingkungan rumah potong ayam dengan gangguan kenyamnan dengan mengambil lokasi penelitian di Kelurahan Bara-Baraya.Usaha peternakan ayam broiler selain mempunyai prospek yang baik untuk dikembangkan juga mempunyai dampak masalah pencemaran lingkungan bagi masyarakat yang bermukim di sekitar RPA.

Hal ini karena usaha ayam dapat menimbulkan polusi udara bau, limbah cair, dan vektor banyaknya lalat yang berkeliaran di kandang dan sekitarnya, dan kekhawatiran masyarakat akan virus flu burung. Untuk itu diperlukan usaha yang tepat untuk mengatasi masalah dampak yang ditimbulkan yaitu dengan menjaga kebersihan, penambahan zeolit dan srarbio probiotik pada pakan.

Berdasarkan karakteristik responden menunjukkan bahwa persentase tingkat umur yang tertinggi dari responden yang tinggal di Kelurahan BaraBaraya Timur Kecamatan Makassar Kota Makassar adalah klasifikasi responden yang berumur 39-49 tahun dengan jumlah 13 orang Kondisi ini menunjukkan bahwa responden lebih banyak dalam kategori umur produktif yang dijumpai pada waktu wawancara. Selain itu berdasarkan jenis kelamin sebagian besar adalah laki-laki yaitu sebanyak 57,14 \%.

Tingkat

Pendidikan formal di Kelurahan BaraBaraya Timur Kecamatan 
Makassar Kota Makassar, menunjukkan bahwa sebagianbesar responden memiliki tingkat pendidikan SMA/sederajat dengan jumlah 25orang dengan persentase $59,52 \%$.

Berdasarkan jarat tempat tinggal dengan RPA bahwa mayoritas responden berjarak sangat dekat dengan lokasi RPA. Pemukiman penduduk yang berada pada jarak antara 0- 50 meter dari lokasi RPA terdapat 35 responden atau $83,33 \%$ sedangkan pada jarak 51-100 meter terdapat 7 responden atau 16,67\%. Keberadaan RPA yang dekat dengan pemukiman penduduk memberikan dampak negative secara kesehatan kepada masyarakat.

\section{Bau}

Bau kotoran ayam sangat menyengat itu merupakan masalah umum peternakan. Masalah itu akan mengakibatkan masalah lingkungan karena dapat menyebabkan pencernaan polusi lingkungan, yakni polusi udara. Dengan adanya bau kotoran yang sangat menyengat hidung, udara disekitar tempat peternakan akan menjadi bau sehingga menyebabkan lingkungan tidak nyaman, bahkan dapat menjadi sumber penyakit di sekitar permukiman penduduk akan menjadi masalah bagi masyarakat sekitar RPA.

Hasil penelitian menunjukan kategori perilaku dalam menyikapi bau kotoran ayam yang menganggu pernapasan dan menyebabkan polusi udara di sekitar pemukiman sehinggah penduduk menjadi masayarakat menjadi tidak nyaman sebanyak 5 orang $(11,90)$ tidak bau, dan 37 orang $(88,09)$ bau, hal ini tentu saja aka berdampak buruk pada orang yang tinggal disekitar RPA maupun pengguna jalan, bahkan sering terjadi kepada pengguna jalan.

Polusi udara (bau) sangat mengganggu masyarakat yang ada di sekitar kandang peternakan ayam.Hal ini dikarenakan kurangnya manajemen dalam pengelolaan limbah. Sebagai contoh keberadaan Sepuluh peternakan ayam yang berada di Kelurahan Bara - Baraya Timur meresahkan warga karena limbah peternakan ayam tersebut menimbulkan bau yang tidak sedap (Anonimous, 2010)

Bau yang tidak sedap ini berasal dari kandungan gas amonia yang tinggi yang terbentuk dari penumpukan feses yang masih basah dalam kondisi anaerob.Gas amonia 
mempunyai pengaruh buruk terhadap manusia dan ternak.

\section{Limbah Cair}

Hasil penelitian tentang Limbah cair penyebab pencemaran lingkunganini dihasilkan oleh air bersih yang telah digunakan untuk berbagai kegiatan menghasilkan limbah cair karena tidak semua air yang digunakan terikut sebagianya terbuang secara langsung ke sungai hal ini menyebabkan pencemaran air sungai dan menghasilkan kehidupan bagi kuman-kuman penyebab penyakit. Dimana terdapat 5 orang $(11,91 \%)$ tidak bau, dan 36 orang (85,71\%) bau. Dampak langsung yang ditimbulkan dari limbah cair ini adalah terganggunya ekosistem air dan tanah yang disebabkan SPAL yang ada tidak memenuhi syarat.Limbah cair adalah satu jenis limbah yang tidak memiliki nilai ekonomis dan dapatmenyebabkan atau menjadi sumber perncemaran air dan lingkungan.

Bila ditinjau secara kimiawi, limbah cair terdiri dari bahan kimia, senyawa organik dan anorganik dengan konsentrasi dan kuantitas tertentu.Limbah cair adalah bahan-bahan pencemar berbentuk cair. Air limbah adalah air yang membawa sampah (limbah) dari rumah tinggal, bisnis, dan industry yaitu campuran air dan padatan terlarut atau tersus pensi dapat jugamerupakanair $b$ uangan dari hasil proses yangdi buang ke dalam lingkungan pencemaran lingkungan dan me mbahayakan kesehatan manusi a, sehingga perlu dilakukanpen anganan dalam proses produksi Rumah Pemotongan Ayam dihasilkan limbah cair yang berasal dari darah ayam, proses pencelupan, pencucian ayam dan peralatan produksi Menurut (Morley, 2008)

Limbah cair biasanya dialirkan secara sembarang tanpa mempedulikan kondisi lingkungan sehingga dapat menimbulkan pencemaran lingkungan. kebiasaan yaitu dibuang di tempat terbuka secara sembarang tempat dan tidak dalam keadaan tertutup.

Limbah cair ini dihasilkan oleh air bersih yang telah digunakan untuk berbagai kegiatan menghasilkan limbah cair karena tidak semua air yang digunakan terikut sebahagianterbuang secara langsung ke sungai, hal ini menyebabkan pencemaran air sungai dan menghasilkan kehidupan bagi kuman-kuman penyebab penyakit (Nuraini 2002).

\section{Vektor}

Vektor adalah arthropoda yang dapat memindahkan atau 
menularkan suatu infection agent dari sumber penyakit infeksi kepada induk yang rentan.Vektor penyakit merupakan arthropoda yang berperang sebagai penularan penyakit sehingga dikenal sebagai vector-brone disease yang merupakan penyakit seringkali bersifat endemism maupun epidemis dan menimbulkan bahaya bagi kesehatan masyarakat. Hasil penelitian menunjukkan bahwa adanya vektor di RPA tersebut akibat pemilik rumah potong ayam kurang menjaga kebersihannya sehingga lalat, nyamuk, virus, dan bakteri tersebut berkembang biak dimana sebanyak $90,47 \%$ orang merasa telah terjadi gangguan kenyamanannya. Selebihnya merasa tidak terganggu karena sudah terbiasa dengan keadaan ini, bahkan mereka sejak lahir sudah merasakannya.

Hasil penelitian ini juga didapatkan bahwa terdapat $80 \%$ titik yang diambil sebagai sampel terdapat vektor penyebab penyakit. Vektor yang ditimbulkan rumah potong ayam tersebut seperti bakteri, jamur, lalat, dan nyamuk yang desebabkan gangguan kenyamanan terhadap masyarakat yang bermukim disekitar (RPA) tersebut sanitasi yang di rumah potong ayam tersebut kurang baik.

Lalat timbul karena kurangnya kebersihan kandang ayam.Lalat adalah jenis serangga yang berasal dari SubOrdo Cyclorrapha Ordo Diptera. Lalat ini dapat menimbulkan berbagai masalah seperti mediator perpindahan penyakit dari ayam yang sakit ke ayam yang sehat, mengganggu pekerja kandang, menurunkan produksi, mencairkan feses atau kotoran ayam yang berakibat meningkatnya kadar amonia dalam kandang (Dedy, 2010). Lalat juga meresahkan masyarakat yang tinggal di pemukiman yang dekat dengan peternakan sehingga menimbulkan protes warga.Oleh karena itu, diperlukan upaya untuk mengurangi keberadaan lalat.

Ada banyak jenis lalat yang ada di permukaan bumi ini, tapi yang paling banyak merugikan manusia adalah jenis lalat rumah (musa domestika), lalat hijau (lucilia), lalat biru (calliphora vumituria), dan lalat latrine

(fannia cunicularis).Selain mengganggu pemandangan lalat juga menimbulkan banyak berbagai penyakit misalnya; disentri, diare, thypoid dan colera. Penyebaran bibit dari berbagai penyakit itu hampir sama yaitu 
dibawa oleh lalat yang berasal dari sampah, kotoran manusia atau hewan, terutama melalui bulu-bulu badannya, kaki dan bagian tubuh yang lain dari lalat lalu hinggap pada makanan manusia. Umumnya gejala dari penyakit ini adalah perut sakit, gangguan pada usus, demam tinggi, sakit kepala dan berak darah.

Secara umum gejala manusia yang terinfeksi flu burung ialah deman tinggi, keluhan pernapasan dan perut, nyeri otot, sakit tenggorokan, batuk dan sesak napas. Menurut (Anonimious 2009).

Apabila dalam 7 hari terakhir unggas dipeternakan terutama jika dalam perkembanganya kondisi tubuh sangat cepat menurun drastis, bila tidak segera ditolong korban bisa meninggal karena komplikasi (gagal nafasdan gangguanfungsi tubuh lainnya).

Pengobatan manusia yang terinfeksi flu burung adalah dengan cara 5 pengobatan antiviral yaitu dengan pemberian antivirus dan penurun panas. Diantaranya antivirus dan penurun panas. Diantara anti virus yang dapat dipakai adalah jenis yang menghambat replikasi dari neuramdase antara lainOseltamivir(Tamiflu) dan Zanamivir.
Dari semua hal di atas ternyata RPA tradisional masih belum dapat memenuhi persyaratan sanitasi dan higiene dalam produksinya. Sehingga harus dilakukan berbagai upaya perbaikan demi menghasilkan karkas ayam yang Aman, Sehat, Utuh, dan Halal (ASUH)

Tempat penjajaan daging ayam juga harus memiliki syaratsyarat sebagai berikut:

1. Terpisah dari tempat penjualan komoditi lain.

2. Bangunannya permanen dengan lantai kedap air dan memiliki ventilasi yang cukup.

3. Meja berlapis porselin putih dan tersedia tempat serta alat penggantung daging yang terbuat dari bahan anti karet.

4. Selalu tersedia air bersih dalam jumlah cukup untuk keperluan pembersihan tempat penjualan dan tempat pencucian tangan.

5. Selalu dalam keadaan bersih. (Syukur, 2006).

Karkas ayam produksi RPA tradisional sebagian besar dipasarkan di pasar-pasar tradisional. Kondisi tempat penjualan sangat dipengaruhi oleh kondisi pasar.Ada sebagian pasar tradisional yang sudah memiliki pengaturan daerah penjualan yang baik, seperti daerah penjualan daging 
dan ikan yang terpisah dari komoditas lainnya.Namun sering juga keterbatasan tempat mengakibatkan tempat penjualan berbagai komoditas saling berbaur.

Sesuai dengan SNI rumah pemotongan ayam tradisional maupun modern harus jauh dari permukiman penduduk, jauh dari polusi dan tidak mencemari lingkungan. Setelah ditinjau kelapangan ternyata masih ada lokasi pemotongan hewan yang berada persis di pinggir jalan raya, walaupun rumah pemotongan ini dalam skala kecil.

Sebagian

besar

penyembelihan ayam di RPA tradisional belum mendapat sentuhan inovasi teknologi yang memadai dan kurang memperhatikan sanitasi pada alat-alat pemotongan dan penanganan karkas sehingga menghasilkan karkas ayam yang bermutu rendah, untuk menghasilkan karkas ayam bermutu, maka sebelum ayam disembelih harus diistirahatkan selama 12-24 jam.

$\mathrm{Hal}$ ini untuk menghindari stres pada ayam. Kondisi stres pada ayam mengakibatkan adanya perubahan glikogen menjadi asam laktat sehingga $\mathrm{pH}$ daging turun menjadi 5-6 dan hal ini memberikan peluang bagi bakteri mikroorganisme lain tumbuh subur yang dapat merusak daging (SNI, 1999). Hasil penelitian ini telah sesuai dengan teori yang dikemukakan oleh Prabowo (2006), yang menyatakan faktor sosial budaya ini merupakan faktor eksternal untuk membentuk perilaku manusia. (sudirman 2016)

\section{KESIMPULAN DAN SARAN Kesimpulan}

Berdasarkan hasil yang diperoleh maka dapat diambil kesimpulan bahwa:

1. Bau yang ditimbulkan di lingkungan Rumah Potong Ayam Kelurahan BaraBaraya Timur Kecamatan Makassar Kota Makassar. Sangat mengganggu masyarakat dan pengguna jalan yang melintasi lokasi tersebut dimana terdapat $70 \%$ respoden yang merasa bau.

2. Limbah di lingkungan Rumah Potong Ayam Kelurahan Bara-Baraya Timur Kecamatan Makassar Kota Makassar masing-masing sangat memprihatinkan dan sangat mengganggu bagi ekosistem dan lingkungan sosial dimana terdapat 80 titik pengambilan sampel 
limbahnya tidak memenuhi syarat.

3. Vektor yang tersebar disekitarRumah Potong Ayam di Kelurahan BaraBaraya Timur Kecamatan Makassar Kota Makassar juga sangat mengganggu kesehatan masyarakat dimana terdapat $80 \%$ titik sampel yang diamati terdapat vektor penyebab penyakit.

\section{Saran}

1. Pengelola Rumah Potong Ayam sebaiknya lebih memperhatikan, kebersihan lingkungan, dan bau yang bersumber dari RPA yangmasih sering dikeluhkanoleh masyarakat sekitar guna menghindari konflik dankelanjutan usahanya dimasa yang akan datang.

2. Untuk masyarakat sekitar agar lebih memperhatikan kondisi lingkungannyadan tidaksegan menegur dan melaporkan kepada pemerintah setempat apabilapengelola rumah potongayam tidak mengelola limbahnya dengan baik.

3. Diharpakan kepada pemerintah untuk rutin melakukan penyuluhan dan pembasmian hama/vektor penyebab penyakit yang ada di Kelurahan Bara-Baraya Timur.

\section{DAFTAR PUSTAKA}

Anonimous. 2009. Apakah flu burung. http://goldgam at.com/infogamat/apakah -fluburung.htm (15 september 2010).

Anonimous. 2009. Pencemaran akibat limbah peternakan dan penanganannya. http:// kalimantankita.blogspot. com/2009/05/pencemar an-akibat-limbahpeternakan.html (15 september 2010).

Anonimous. 2010. Serangan lalat dari peternakan ayam resahkan warga Pebayuran. http://www. pikiranrakyat.com/node/11293 2 (15 september 2010).

Anonimous.2009. Flu burung pada

manusia. http://fevercli nic.wordpress.com/200 9/ 07/31/flu-burungpada-manusia (15 september 2010).

Badan Standarisasi Nasional. 1999. Standar Nasional Indonesia (SNI) 016159- 1999 Rumah Potong Hewan. Jakarta: BSN 
Dedy. 2010. Mengenal Parasit

\section{Lalat.}

http://dedykoe.blogspot. com/2010/02/mengenal parasit-lalat.html

DepKes RI. (2004). Higiene Sanitasi Makanan dan Minuman. Jakarta: Dirjen PPM dan PL

Morley Nick, Bartlett C, Deegan K. 2008.Mapping Waste in the Food Industry.Oakdede Hollins for Defra and the Food and Drink Federation.

Mulia, 2005. Kesehatan Lingkungan, Graha IImu, Jakarta.

Nuraini.2002.

Campuran

Ampas Sagu dan Enceng Gondok Fermentasi Sebagai Pakan Ayam Buras. Laporan Penelitian Hibah Bersaing Tahun 2002. Fakultas

Peternakan Universitas Andalas, Padang.

Soekidjo Notoatmodjo. (2003).

Pendidikan dan

Perilaku Kesehatan. Jakarta: Rineka Cipta
Sudirman, S. and Krisna, A., 2016. Faktor Yang Berhubungan Dengan Kejadian Penyakit Malaria Di Desa Bobalo Kecamatan Palasa Kabupaten Parigi Moutong Tahun 2013. Healthy Tadulako, 1(1).

Sugiyono, 2003.Statistik Untuk Penelitian. CV. Alfabeta, Bandung.

Syukur, D. A., 2006. Penerapan Higiene-Sanitasi dalam Penyediaan Pangan Asal Hewan yang

ASUH. <URL> http://ww w.disnakkeswanlampung.go.id (diakses tanggal 26 Juli 2006)

Tjiptadi, W. 1990.Pengendalian Limbah Pertanian. Makalah pada Perdidikan Kependudukan dan Lingkungan Hidup Bagi Wydiasnara Sespa, Sepadya, Sepala dan Sespa Antar Departemen. Jakarta. 